\title{
Carbonation and decarbonation reactions: Implications for planetary habitability of
}

\author{
E.M. Stewart ${ }^{1, *} \uparrow$, Jay J. Ague ${ }^{1}$, John M. Ferry ${ }^{2}$, Craig M. Schiffries ${ }^{3}$, Ren-Biao TaO ${ }^{4}$, \\ TERry T. ISSON ${ }^{1,5}$, AND NOAH J. PlanAVSKY ${ }^{1}$
}

\author{
${ }^{1}$ Department of Geology \& Geophysics, Yale University, P.O. Box 208109, New Haven, Connecticut 06520-8109, U.S.A. \\ ${ }^{2}$ Department of Earth and Planetary Sciences, Johns Hopkins University, 3400 N. Charles Street, Baltimore, Maryland 21218, U.S.A. \\ ${ }^{3}$ Geophysical Laboratory, Carnegie Institution for Science, 5251 Broad Branch Road NW, Washington, D.C. 20015, U.S.A. \\ ${ }^{4}$ School of Earth and Space Sciences, MOE Key Laboratory of Orogenic Belt and Crustal Evolution, Peking University, Beijing 100871, China \\ ${ }^{5}$ School of Science, University of Waikato, 101-121 Durham Street, Tauranga 3110, New Zealand
}

\begin{abstract}
The geologic carbon cycle plays a fundamental role in controlling Earth's climate and habitability. For billions of years, stabilizing feedbacks inherent in the cycle have maintained a surface environment that could sustain life. Carbonation/decarbonation reactions are the primary mechanisms for transferring carbon between the solid Earth and the ocean-atmosphere system. These processes can be broadly represented by the reaction: $\mathrm{CaSiO}_{3 \text { (wollastonite) }}+\mathrm{CO}_{2 \text { (gas) }} \leftrightarrow \mathrm{CaCO}_{3 \text { (calcite) }}+\mathrm{SiO}_{2 \text { (quartz) }}$. This class of reactions is therefore critical to Earth's past and future habitability. Here, we summarize their significance as part of the Deep Carbon Obsevatory's "Earth in Five Reactions" project. In the forward direction, carbonation reactions like the one above describe silicate weathering and carbonate formation on Earth's surface. Recent work aims to resolve the balance between silicate weathering in terrestrial and marine settings both in the modern Earth system and through Earth's history. Rocks may also undergo carbonation reactions at high temperatures in the ultramafic mantle wedge of a subduction zone or during retrograde regional metamorphism. In the reverse direction, the reaction above represents various prograde metamorphic decarbonation processes that can occur in continental collisions, rift zones, subduction zones, and in aureoles around magmatic systems. We summarize the fluxes and uncertainties of major carbonation/decarbonation reactions and review the key feedback mechanisms that are likely to have stabilized atmospheric $\mathrm{CO}_{2}$ levels. Future work on planetary habitability and Earth's past and future climate will rely on an enhanced understanding of the long-term carbon cycle.

Keywords: Decarbonation, carbonation, Urey reaction, carbon flux; Earth in Five Reactions: A Deep Carbon Perspective
\end{abstract}

\section{INTRODUCTION}

Life has existed on planet Earth for more than three billion years. In that time there have been profound changes in the brightness of the Sun, the temperature of the deep Earth, and even the length of a day, yet throughout all of these changes, the environment has remained stable enough to support life. The global carbon cycle is generally agreed to have played a critical role in maintaining this habitable climate on Earth. Carbon dioxide $\left(\mathrm{CO}_{2}\right)$ acts as a greenhouse gas, in effect trapping solar energy and raising the temperature of the planet. Over geologic timescales (about one million years or longer), carbon is exchanged between the solid Earth and the atmosphere. The rate of atmospheric $\mathrm{CO}_{2}$ removal increases with temperature, thus the exchange acts as a global thermostat, stabilizing atmospheric $\mathrm{CO}_{2}$ concentrations and therefore moderating Earth's surface temperature. Carbon dioxide is exchanged between the solid Earth and the atmosphere via carbonation reactions such as the archetypal:

\footnotetext{
* E-mail: emily.stewart@yale.edu

of Open access: Article available to all readers online.

$\dagger$ Special collection papers can be found online at http://www.minsocam.org/MSA/

AmMin/special-collections.html.
}

$$
\mathrm{CaSiO}_{3 \text { (wollastonite) }}+\mathrm{CO}_{2 \text { (gas) }} \leftrightarrow \mathrm{CaCO}_{3 \text { (calcite) }}+\mathrm{SiO}_{2 \text { (quartz) }}
$$

and its reverse, decarbonation:

$$
\mathrm{CaCO}_{3 \text { (calcite) }}+\mathrm{SiO}_{2 \text { (quartz) }} \leftrightarrow \mathrm{CaSiO}_{3 \text { (wollastonite) }}+\mathrm{CO}_{2 \text { (fluid) }}
$$

Consequently, these reactions are critical controls on the longterm atmospheric composition, climate, and habitability of Earth, and they form an essential piece of the Deep Carbon Observatory's "Earth in Five Reactions" initiative (introduced by Li et al. 2019). Note that these two simple reactions are used to represent many decarbonation/carbonation reactions involving other cations (especially $\mathrm{Mg}^{2+}$ ) and other silicate minerals (see below).

Carbonation reactions such as reaction 1 occur when carbon in a gas or fluid reacts with silicate minerals to form a solid, commonly a carbonate mineral. Studies of these reactions have a long history in petrology and geochemistry. As early as 1894, the Swedish chemist Arvid G. Högbom suggested that geologic processes could remove $\mathrm{CO}_{2}$ from the atmosphere (Högbom 1894; see review by Berner 1995). In particular, the weathering of silicate rocks provides the necessary chemistry to form carbonate minerals, ultimately transforming gaseous $\mathrm{CO}_{2}$ into solid rock. This fundamental carbonation reaction was discussed in detail 
by Nobel Prize-winning chemist Harold Urey more than 50 years later. In his 1952 book, The Planets, Urey rearticulated the relationship between carbonate and silicate rocks, writing reaction 1 , known today as one of the "Urey reactions." Furthermore, he suggested that such reactions have controlled atmospheric $\mathrm{CO}_{2}$ concentrations throughout Earth history.

Decarbonation (e.g., reaction 2) generally occurs when a rock containing carbonate minerals, such as a siliceous limestone, is metamorphosed at elevated temperatures and pressures. Victor Moritz Goldschmidt (1912) was the first to recognize the significance of metamorphic decarbonation. Goldschmidt noted that the minerals quartz $\left(\mathrm{SiO}_{2}\right)$ and calcite $\left(\mathrm{CaCO}_{3}\right)$ react to form wollastonite $\left(\mathrm{CaSiO}_{3}\right)$ and $\mathrm{CO}_{2}$ gas when a rock is heated to a high enough temperature; his work was among the earliest to use thermodynamic principles to calculate a mineral equilibrium and to quantitatively constrain the conditions of metamorphism.

Norman L. Bowen (1940) demonstrated that, depending on bulk composition, 13 different decarbonation reactions might occur as a siliceous limestone or dolomite is progressively heated. In 1956, Harker and Tuttle produced wollastonite in the laboratory via reaction 2 . Their experiments more tightly constrained the $P-T$ (pressure-temperature) conditions of reaction, yet, remarkably, Goldschmidt's thermodynamic estimate from more than 40 years earlier was close to their result.

Today, researchers continue to study carbonation/decarbonation reactions in essentially all of Earth's geotectonic settings (Fig. 1) through numerical simulations, measurements of modern $\mathrm{CO}_{2}$ fluxes, and examination of the history preserved in the rock record. A detailed accounting of the rates, timing, location, and magnitude of these reactions is essential to understanding $\mathrm{CO}_{2}$ fluxes and our planet's past, present, and future habitability.

\section{CARBONATION}

\section{The Urey reactions}

The two Urey reactions, one of which is mentioned above, are the quintessential exemplars of carbonation reactions on Earth. The other reaction is quite similar to reaction 1 and may run in parallel. The only difference is that it involves the $\mathrm{Mg}^{2+}$ cation instead of $\mathrm{Ca}^{2+}$ :

$$
\mathrm{MgSiO}_{3 \text { (enstatite) }}+\mathrm{CO}_{2 \text { (gas) }} \leftrightarrow \mathrm{MgCO}_{3 \text { (magnesite) }}+\mathrm{SiO}_{2 \text { (quartz) }} \text {. }
$$

From here forward we will focus our discussion on reaction 1, but note that reaction 3 functions essentially identically (Urey 1952).

In fact, reactions 1 and 3 as written do not often occur on the surface of the Earth. For one, the mineral wollastonite actually makes up very little of the Earth's crust. About $50 \%$ of the crust is composed of feldspars (e.g., Ronov et al. 1990). These are also silicate minerals, but with more complicated chemistry and extensive solid solution. Plagioclase feldspars, for example, are a solid solution between $\mathrm{CaAl}_{2} \mathrm{Si}_{2} \mathrm{O}_{8}$ (anorthite) and $\mathrm{NaAlSi}_{3} \mathrm{O}_{8}$ (albite). In nature, weathering of these more complex Ca-bearing silicates may produce phases in addition to calcite and quartz, such as aluminous clays. Similarly, reaction 3 references the carbonate mineral magnesite, which is also relatively rare on Earth's surface in its pure form. Thus reactions 1 and 3 are used as exemplars of carbonation reactions in general but do not reflect the typical mineralogy involved.

Additionally, on Earth's surface, carbonation reactions involve a series of reaction steps as follows (after Siever 1968).

First, $\mathrm{CO}_{2}$ gas in the atmosphere is dissolved in water $\left(\mathrm{H}_{2} \mathrm{O}\right)$ to form carbonic acid $\left(\mathrm{H}_{2} \mathrm{CO}_{3}\right)$ :

$$
\mathrm{CO}_{2 \text { (gas) }}+\mathrm{H}_{2} \mathrm{O}_{\text {(liquid) }} \leftrightarrow \mathrm{H}_{2} \mathrm{CO}_{3 \text { (aqueous) }}
$$

This carbonic acid can dissociate to form a negatively charged bicarbonate anion $\left(\mathrm{HCO}_{3}^{-}\right)$and positively charged $\mathrm{H}^{+}$cation:

$$
\mathrm{H}_{2} \mathrm{CO}_{3 \text { (aqueous) }} \leftrightarrow \mathrm{HCO}_{3 \text { (aqueous) }}^{-}+\mathrm{H}_{\text {(aqueous) }}^{+}
$$

The acidity $\left(\mathrm{H}^{+}\right.$cations) in the water allows a calcium-bearing silicate mineral, here wollastonite $\left(\mathrm{CaSiO}_{3}\right)$, to dissolve and form silicic acid $\left(\mathrm{H}_{4} \mathrm{SiO}_{4}\right)$ :

$$
\begin{aligned}
& \mathrm{CaSiO}_{3 \text { (wollastonite) }}+2 \mathrm{H}_{\text {(aqueous) }}^{+}+\mathrm{H}_{2} \mathrm{O}_{\text {(liquid) }} \leftrightarrow \\
& \mathrm{Ca}_{\text {(aqueous) }}^{2+}+\mathrm{H}_{4} \mathrm{SiO}_{4} \text { (aqueous). }
\end{aligned}
$$

The $\mathrm{Ca}^{2+}$ cation is now free to react with the $\mathrm{HCO}_{3}^{-}$anions to form the mineral calcite $\left(\mathrm{CaCO}_{3}\right)$, more $\mathrm{CO}_{2}$, and water:

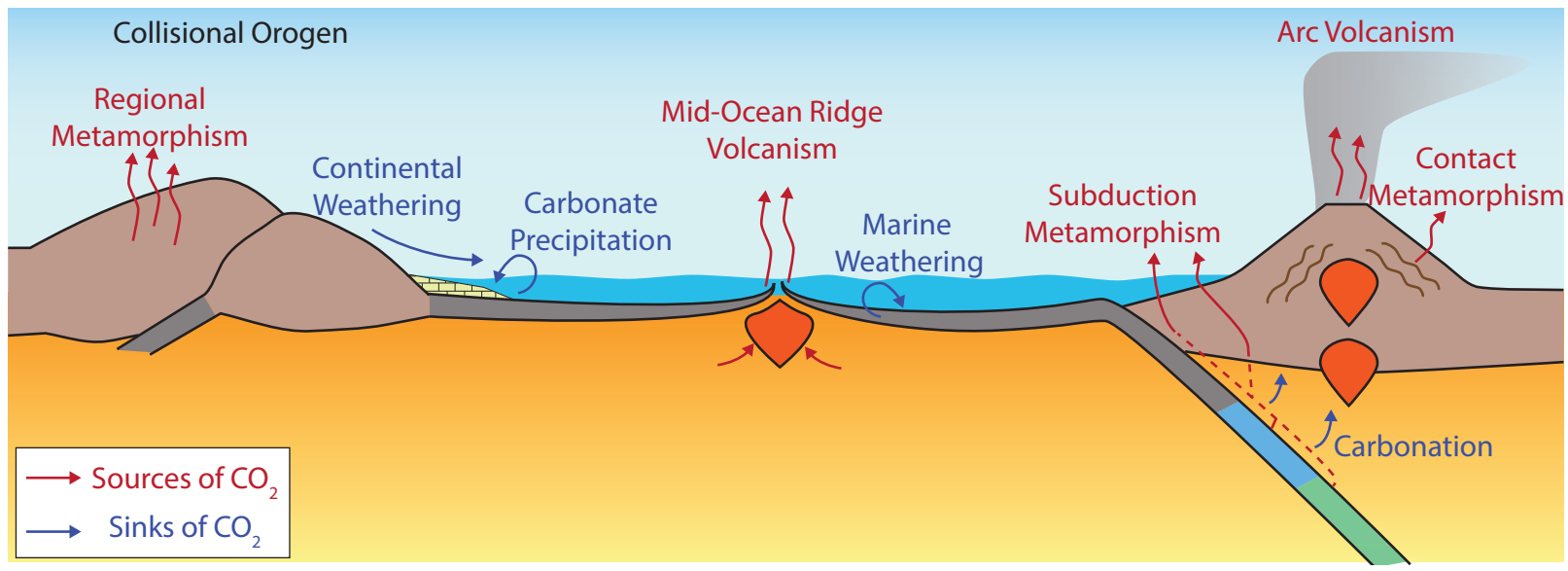

FIGURE 1. Schematic cross section showing the tectonic context of major carbonation/decarbonation processes. Sources of atmospheric $\mathrm{CO}_{2}$ are indicated in red, whereas sinks are in blue. 


$$
\begin{aligned}
& \mathrm{Ca}_{\text {(aqueous) }}^{2+}+2 \mathrm{HCO}_{3 \text { (aqueous) }}^{-} \leftrightarrow \\
& \mathrm{CaCO}_{3 \text { (calcite) }}+\mathrm{CO}_{2 \text { (gas) }}+\mathrm{H}_{2} \mathrm{O}_{\text {(liquid) }} .
\end{aligned}
$$

Finally, the mineral quartz $\left(\mathrm{SiO}_{2}\right)$ may grow from the silicic acid in solution with more water as a by-product:

$$
\mathrm{H}_{4} \mathrm{SiO}_{4 \text { (aqueous) }} \leftrightarrow \mathrm{SiO}_{2 \text { (quartz) }}+2 \mathrm{H}_{2} \mathrm{O}_{\text {(liquid) }}
$$

We can sum up these five sub-reactions (doubling reactions $1 \mathrm{~A}$ and $1 \mathrm{~B}$ for balance) to make one total reaction:

$$
\begin{aligned}
& 2 \mathrm{CO}_{2(\mathrm{~g})}+3 \mathrm{H}_{2} \mathrm{O}_{(\mathrm{l})}+2 \mathrm{H}_{2} \mathrm{CO}_{3(\mathrm{aq})}+\mathrm{CaSiO}_{3(\mathrm{wol})}+2 \mathrm{H}_{(\mathrm{aq})}^{+}+ \\
& \mathrm{Ca}_{(\mathrm{aq})}^{2+}+2 \mathrm{HCO}_{3(\mathrm{aq})}^{-}+\mathrm{H}_{4} \mathrm{SiO}_{4(\mathrm{aq})} \leftrightarrow \\
& 2 \mathrm{H}_{2} \mathrm{CO}_{3(\mathrm{aq})}+2 \mathrm{HCO}_{3(\mathrm{aq})}^{-}+2 \mathrm{H}_{(\mathrm{aq})}^{+}+\mathrm{Ca}_{(\mathrm{aq})}^{2+}+ \\
& \mathrm{H}_{4} \mathrm{SiO}_{4(\mathrm{aq})}+\mathrm{CaCO}_{3(\mathrm{cc})}+\mathrm{CO}_{2(\mathrm{~g})}+3 \mathrm{H}_{2} \mathrm{O}_{(\mathrm{l})}+\mathrm{SiO}_{2(\mathrm{q})}
\end{aligned}
$$

and by cancelling species present on both sides of the reaction return to the simplified reaction 1 .

This reaction sequence has several important aspects to note. First, there are some nuances of the full reaction $1 \mathrm{~F}$ that one cannot observe in the simplified reaction 1 . For example, the full reaction $1 \mathrm{~F}$ is only $50 \%$ efficient at storing $\mathrm{CO}_{2}$; for every two molecules of $\mathrm{CO}_{2}$ that are dissolved in water, only one molecule is transformed into calcite while the other molecule is re-released as $\mathrm{CO}_{2}$ gas. Second, note also that each of the steps may occur at a different point in space and time. A silicate mineral may weather and dissolve in a river in the middle of a continent (reaction 1C), but the $\mathrm{Ca}^{2+}$ ion may travel thousands of kilometers before forming calcite in the ocean (reaction 1D). Since the evolution of marine calcifiers, carbonate mineral precipitation has often been facilitated by biological processes (e.g., the formation of a foraminifera skeleton), although abiotic precipitation also occurs. In either case, the formation of carbonate minerals from solution functions as a key piece of this Urey reaction sequence.

The most important take-away from the Urey reactions is this: surface carbonation reactions are a major sink for atmospheric $\mathrm{CO}_{2}$. In fact, more than $99 \%$ of all carbon in the crust, biosphere, and ocean-atmosphere system is stored in sedimentary and metasedimentary rocks (e.g., Archer 2010). Throughout
Earth history, carbonation has been the primary way that $\mathrm{CO}_{2}$ is removed from the atmosphere (Urey 1952), and without this process life on Earth could not exist (e.g., Berner and Caldeira 1997). For comparison, consider our neighboring planet, Venus, where the Urey reactions rarely occur. Much less carbon is stored in the solid rock of Venus, thus the Venusian atmosphere contains massive amounts of $\mathrm{CO}_{2}$, contributing to average surface temperatures of more than $400{ }^{\circ} \mathrm{C}$ (Sagan 1962).

\section{Silicate weathering}

On geologic timescales, silicate weathering is the ratelimiting step of the Urey reaction. Because $\mathrm{CO}_{2}$ dissolution, carbonic acid dissociation, and the other intermediate reactions occur relatively quickly, the availability of silicate-bound $\mathrm{Ca}^{2+}$ (or $\mathrm{Mg}^{2+}$ ) (reaction 1C) is of critical importance. This can be thought of in terms of the seawater's alkalinity, that is, its ability to neutralize acid. Silicate weathering increases the alkalinity of the seawater that drives carbonate precipitation. Note that any contribution to total alkalinity drives carbonation, thus weathering of $\mathrm{Mg}$-silicate minerals could ultimately drive the formation of Ca-carbonates.

Traditionally, geologists have considered continental rocks to be the primary contribution to global silicate weathering (e.g., Walker et al. 1981; Berner et al. 1983). Continental weathering depends on a sequence of discrete processes. First, continental rocks must be exposed at Earth's surface. Surface rocks are then physically (or mechanically) weathered, that is, broken apart into smaller pieces. Chemical weathering can then occur on the exposed surfaces (as seen in Fig. 2a), partially dissolving the rock and releasing aqueous ions (i.e., reaction $1 \mathrm{C}$ ). There is a positive association between physical and chemical weatheringmineral dissolution can contribute to denudation while physical weathering can expose more reactive surface area and facilitate chemical weathering. The ions resulting from weathering are transported by rivers and ultimately delivered to the ocean where they continue along the Urey reaction sequence.

Many key factors can affect the rate of continental weathering. For example, tectonic collisions that form high mountain belts help to expose more rock at Earth's surface, which may increase

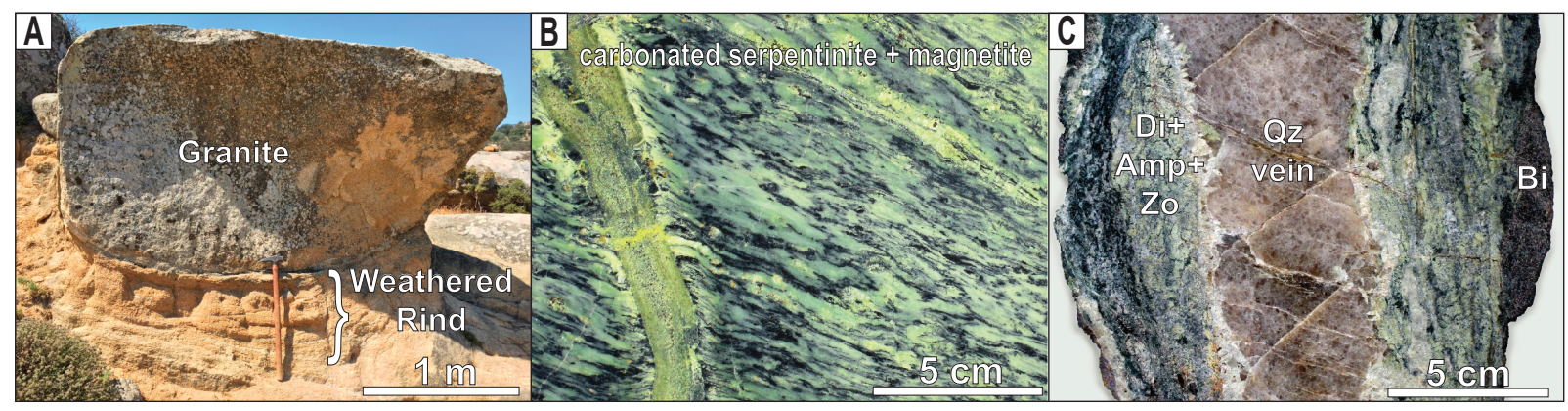

FIGURE 2. Photographs of carbonation/decarbonation processes. (a) Silicate weathering: granite exposed at Earth's surface undergoes spheroidal weathering resulting in discrete boulders with thick physical and chemical weathering rinds. Volax, Tinos Island, Greece. (b) High-temperature carbonation: yellow Ni-bearing calcite has precipitated in an ultramafic rock of the Maltby Lakes Metavolcanics, Connecticut. (c) Infiltration-driven decarbonation: quartz vein (center; Qz) with diopside (Di) + amphibole (Amp) + zoisite (Zo) selvages cutting biotite-bearing metacarbonate rock (dark margins; Bi) of the Wepawaug Schist, Connecticut. Prograde reactions, such as Phlogopite +3 Calcite +6 Quartz $=3$ Diopside $+\mathrm{K}$-feldspar $+3 \mathrm{CO}_{2}+\mathrm{H}_{2} \mathrm{O}$, generated significant $\mathrm{CO}_{2}$ (Ague 2003; Stewart and Ague 2018). 
the potential for weathering (e.g., Raymo and Ruddiman 1992; Edmond et al. 1995; Dessert et al. 2003). Increased precipitation can lead to more physical erosion, and the additional water can also drive more chemical weathering $\left(\mathrm{H}_{2} \mathrm{O}\right.$ is a necessary reactant in reaction 1C) (Jenny 1941; Loughnan 1969; Amiotte et al. 1995; White and Blum 1995; Maher and Chamberlain 2014). At higher temperatures any chemical reaction will have a faster reaction rate (Arrhenius 1915); thus, increasing surface temperatures may result in faster continental weathering (Walker et al. 1981; Berner et al. 1983; Manabe and Stouffer 1993).

\section{Marine weathering}

More recently, some researchers have proposed that marine weathering processes have an important role to play in global carbon cycling (e.g., Staudigel et al. 1989; Brady and Gíslason 1997; Wallmann et al. 2008; Coogan and Gillis 2013; Coogan and Dosso 2015). The concept is the same; silicate minerals undergo chemical reaction that supplies alkalinity to the oceans and helps form carbonate minerals. Marine weathering can occur within the marine sediment pile (e.g., Wallmann et al. 2008; Solomon et al. 2014) or in basalts in "off axis" hydrothermal systems (Coogan and Dosso 2015). Evidence for chemical weathering of silicate minerals within the sediment pile comes from deep anoxic (oxygen-free) sediments (Wallmann et al. 2008; Solomon et al. 2014).

In "off-axis" hydrothermal systems, large amounts of seawater flow through the oceanic crust (off-axis simply refers to the fact that these systems are not located directly adjacent to mid-ocean ridge volcanoes). Along its flow path the water is heated to moderate temperatures (tens of degrees Celsius) and dissolves silicate minerals as in reaction $1 \mathrm{C}$. Once again, this dissolution delivers the alkalinity that allows carbonate minerals to form (e.g., Staudigel et al. 1989; Brady and Gíslason 1997; Gillis and Coogan 2011). Hydrothermal circulation may also affect ultramafic rocks, creating carbonated serpentinites in both mid-ocean ridge and off-axis systems (Kelemen et al. 2011). The impact these marine processes have on global carbon cycling may be just as significant as the effect of continental weathering (e.g., Wallmann et al. 2008; Coogan and Dosso 2015).

\section{Reverse weathering}

Reverse weathering refers to the formation of silicate clay minerals from solution. It is "reverse" weathering in the sense that it consumes the alkalinity and silica that the forward silicate weathering reaction 1C provides (Sillén 1961; Garrels 1965; Mackenzie and Garrels 1966). Reverse weathering is regarded as a net positive source of atmospheric $\mathrm{CO}_{2}$. In other words, reverse weathering allows for efficient recycling of carbon within the ocean-atmosphere system, elevating atmospheric $\mathrm{CO}_{2}$ concentrations. Recent work suggests that changes in the amount of reverse weathering may have had profound climatic impacts over the course of Earth history (Isson and Planavsky 2018).

\section{High-temperature carbonation in subduction zones and orogens}

Carbonation reactions also take place deeper in Earth and at higher pressure-temperature conditions. High-temperature carbonation occurs via many different reactions that are ex- emplified by reaction 1 . When $\mathrm{CO}_{2}$-bearing fluid infiltrates a silicate rock (especially a mafic or ultramafic rock with a high concentration of $\mathrm{Mg}^{2+}$ ) this fluid may react with the silicate minerals, removing $\mathrm{CO}_{2}$ from the fluid phase and forming new carbonate minerals (see Fig. 2b). The particular silicate minerals involved in the reaction will depend upon the rock composition and the $P$ - $T$ conditions.

One locus of such carbonation is the mantle wedge above a subducting slab (Falk and Kelemen 2015; Piccoli et al. 2016, 2018; Scambelluri et al. 2016). As oceanic crust is subducted into the mantle, it releases fluid into the overriding plate. This fluid may be dominantly $\mathrm{H}_{2} \mathrm{O}$, but subduction zone decarbonation reactions may supply $\mathrm{CO}_{2}$ as well (see section on decarbonation). The ultramafic rocks of the mantle are highly reactive with $\mathrm{CO}_{2}$ fluids, so when the slab-derived fluid rises into the mantle, carbonation reactions are fast (Sieber et al. 2018). Because the degree of carbonation increases with lower temperatures (Sieber et al. 2018), mantle wedge carbonation probably dominates in the cooler (but still hot at $<\sim 700{ }^{\circ} \mathrm{C}$ ) fore-arc region and is less pronounced in the hotter mantle directly below the volcanic arc.

The fate of this carbonated mantle is not well known. It may serve as a location of long-term deep carbon storage (Kelemen and Manning 2015). Alternatively, melting of carbonated mantle material may ultimately contribute $\mathrm{CO}_{2}$ to the atmosphere when the melt erupts from overlying arc volcanoes (Kerrick and Connolly 2001; Gorman et al. 2006; Kelemen and Manning 2015; Mason et al. 2017).

Similar high-temperature carbonation of ultramafic rocks can also occur in orogenic belts during prograde regional (Evans and Trommsdorff 1974; Ferry et al. 2005) and contact (Ferry 1995) metamorphism. In addition, fluid infiltration during retrograde metamorphism (i.e., metamorphism as rocks cool down from peak T) may drive carbonation reactions. For example, the mineral wollastonite is stable at high temperatures (see below). As the temperature falls, the wollastonite will react with any available $\mathrm{CO}_{2}$ to create calcite and quartz (Ferry 2000). Critically, this retrograde carbonation reaction cannot occur in the absence of a $\mathrm{CO}_{2}$-bearing fluid (Tian and Ague 2014).

\section{DECARBONATION}

Decarbonation reactions, such as reaction 2, are a major source of atmospheric $\mathrm{CO}_{2}$ in geologic history. In the example reaction, a carbonate mineral (calcite) reacts with a silicate mineral (quartz) to form the Ca-silicate mineral wollastonite and $\mathrm{CO}_{2}$. Reaction 2 represents myriad decarbonation reactions that all share these features: (1) a carbonate mineral reacts with a silicate mineral, (2) a new silicate mineral is formed using divalent cations from the carbonate (e.g., $\mathrm{Ca}^{2+}, \mathrm{Mg}^{2+}, \ldots$ ), and (3) $\mathrm{CO}_{2}$ is released. (Rarely, decarbonation reactions may occur in the absence of silicate minerals when a carbonate mineral breaks down into a mineral oxide and $\mathrm{CO}_{2}$.)

Increasing temperature drives decarbonation. Certain carbonate-silicate mineral assemblages (such as calcite and quartz) are only stable together up to a certain temperature at a given pressure and fluid composition. When the temperature rises beyond that point, they react and release $\mathrm{CO}_{2}$ (Goldschmidt 1912; Bowen 1940; Harker and Tuttle 1956). Figure 4 is a $P-T$ phase diagram showing that mineral assemblage is stable at a 


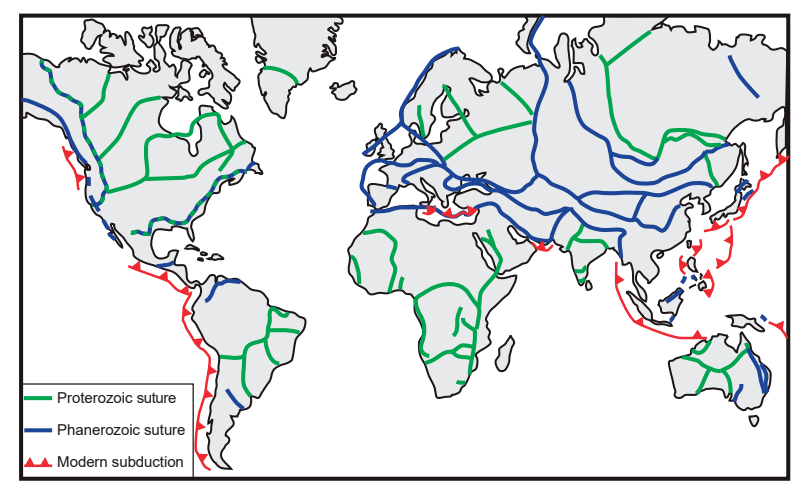

FIGURE 3. Global map indicating the locations of modern subduction (red lines with carets), and ancient sutures formed in the Phanerozoic (blue) and Proterozoic (green). Sutures that were active during both eons are dashed blue and green. Modified after Orme (2015) and Burke et al. (1977).

given $P-T$ condition and fluid composition.

Therefore, these reactions generally occur when a mixed carbonate-silicate rock undergoes significant increases in temperature and pressure (Goldschmidt 1912; Bowen 1940; Harker and Tuttle 1956). On Earth, this can take place via prograde metamorphism, that is, metamorphism of a rock driven in part by increasing temperature. Geologists recognize different categories of metamorphism relating to different tectonic environments (Fig. 1).

\section{Contact metamorphism}

Contact metamorphism occurs when a magma intrudes into solid rocks, and so can be located anywhere volcanism and/or magmatism are active (Delesse 1858). In contact metamorphism, rocks are not necessarily tectonically buried; they are simply heated by the adjacent magma. Therefore, pure contact metamorphism is associated with higher geothermal gradients (e.g., high temperatures at relatively low pressures) compared to regional metamorphism. Additionally, it is more restricted in area, occurring in haloes (aureoles) around magmatic intrusions. It has been suggested that degassing in contact aureoles around large igneous provinces drove catastrophic global warming associated with some of Earth's largest mass extinctions (e.g., Ganino and Arndt 2009; Burgess et al. 2017), but the relative importance of this metamorphism remains debated (e.g., Nabelek et al. 2014).

\section{Regional metamorphism}

Regional-scale metamorphism takes place where two tectonic plates converge and ultimately collide (subduction zones and continental collisions) or pull apart (e.g., continental rifts) (Kennedy 1948; Miyashiro 1972). Figure 3 shows a map of both modern and ancient collisional belts on Earth. As can be seen, such convergent plate boundaries are common features. During regional-scale metamorphism, rocks are subjected to both high pressures $(\sim 0.2$ to more than $2.0 \mathrm{GPa})$ and high temperatures $\left(\sim 250\right.$ up to $\left.\sim 1000{ }^{\circ} \mathrm{C}\right)$. Note that wollastonite is a relatively uncommon mineral in regionally metamorphosed rocks, and other silicate minerals, such as biotite and plagioclase, are more commonly produced (Ferry 1988).

\section{Decarbonation in subduction zones}

Subduction zones are a particularly important setting of $\mathrm{CO}_{2}$ exchange. As oceanic crust sinks into the mantle, it brings carbon-bearing minerals into the deeper Earth (Plank and Langmuir 1998). However, metamorphic decarbonation reactions in both the subducting slab and the overriding plate may consume carbonate minerals and release $\mathrm{CO}_{2}$ back toward the surface. Thus, subduction may transfer carbon from the crust into the ocean-atmosphere system or into the deep mantle.

Another mechanism of $\mathrm{CO}_{2}$ production has recently been documented in subduction zones. In the presence of a fluid, carbonate minerals may undergo congruent carbonate dissolution such as:

$$
\mathrm{CaCO}_{3 \text { (calcite) }}+2 \mathrm{H}_{\text {(aq) }}^{+} \leftrightarrow \mathrm{H}_{2} \mathrm{O}_{\text {(fluid) }}+\mathrm{Ca}_{\text {(aq) }}^{2+}+\mathrm{CO}_{2 \text { (aq) }}
$$

(Frezzotti et al. 2011; Ague and Nicolescu 2014). The $\mathrm{CO}_{2(\mathrm{aq})}$ in reaction 4 represents aqueous carbon species in general; carbonate and bicarbonate ions (Pan and Galli 2016), as well as organic carbon species (Sverjensky et al. 2014), may be more important at depth. This reaction is different from reaction 2 in two important ways: First, it does not require the presence of a silicate mineral to proceed, and it could, therefore, occur in a pure carbonate rock. Second, it has the potential to be highly efficient at releasing carbon. For example, in subducted rocks on the Greek islands of Syros and Tinos, carbonate dissolution released $60-90 \%$ of the solid carbon from some rocks, while decarbonation reactions might be expected to release considerably less (Ague and Nicolescu 2014). Thus, a small proportion of carbonate dissolution could have a relatively large effect.

Whatever the decarbonation mechanism, $\mathrm{CO}_{2}$ released by subducting rocks may follow several paths. It could flow through the many kilometers of overriding lithosphere (or perhaps along the subduction interface) to escape to the atmosphere as part of a diffuse (i.e., spatially widespread) metamorphic flux (e.g., Sakai et al. 1990; Sano and Williams 1996; Campbell et al. 2002), or it could become trapped in the overlying mantle wedge by a carbonation reaction (e.g., Piccoli et al. 2016, 2018; Scambelluri et al. 2016; Sieber et al. 2018). Once in the mantle wedge, that carbon could be stored for millions of years. If carbonated mantle melts, however, this carbon could form part of a magma and ultimately be released to the atmosphere as part of the arc volcanic $\mathrm{CO}_{2}$ flux (Varekamp et al. 1992; Kelemen and Manning 2015; Poli 2015). Thus, decarbonation in a subducted slab could contribute $\mathrm{CO}_{2}$ to both a diffuse metamorphic flux and the associated volcanic flux.

Decarbonation reactions also occur in the overriding plate in subduction zones, driven by elevated temperatures from magma ascent and magmatic dewatering that would result in aqueous fluid infiltration. This decarbonation flux should be more significant in continental arcs with thick carbonate layers and less prominent when subduction occurs beneath oceanic crust (i.e., island arcs). Lee et al. (2013) recognized a relationship between total continental arc length and global temperature in the past. They suggested that contact metamorphism-driven decarbonation in these continental arcs may be an important source of atmospheric $\mathrm{CO}_{2}$. 


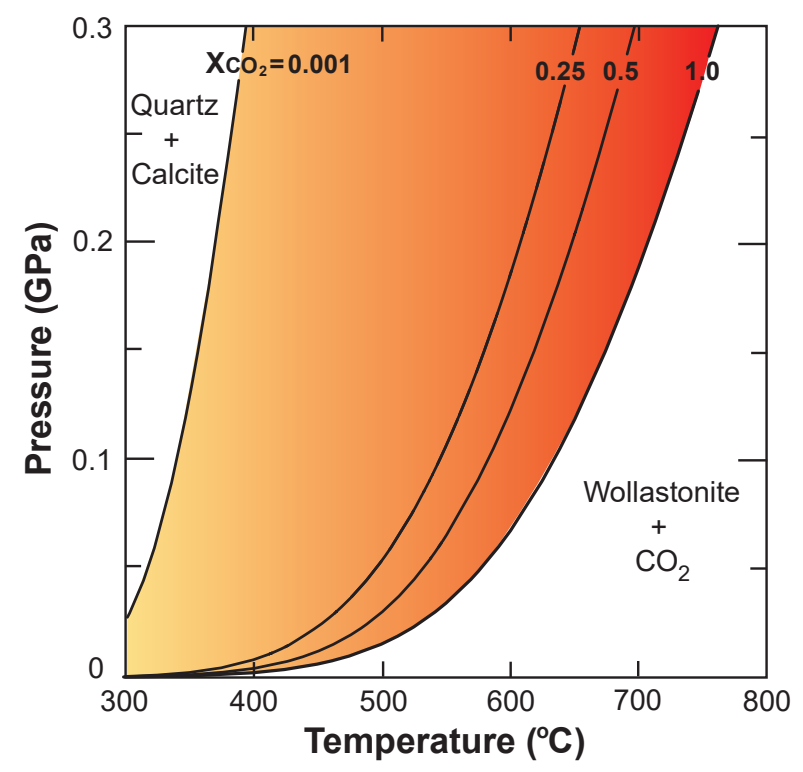

FIGURE 4. Pressure-Temperature diagram showing the stability of the assemblage calcite + quartz relative to wollastonite $+\mathrm{CO}_{2}$. Conditions of this reaction are calculated for equilibrium between minerals and fluid of differing $\mathrm{CO}_{2}$ content $\left(\mathrm{X}_{\mathrm{CO}_{2}}\right.$ is the mole fraction of $\mathrm{CO}_{2}$ in fluid). Calculations made using the program Theriak-Domino (de Capitani and Petrakakis 2010) with the Holland and Powell (1998) database.

\section{Infiltration-driven decarbonation}

The presence of a water-bearing fluid (either liquid or gas) has a profound effect on the stability of carbonate minerals. Metamorphism in a closed system will not evolve much $\mathrm{CO}_{2}$ until relatively high temperatures are reached (Greenwood 1975). On the other hand, infiltration of a water-rich fluid into a reactive rock can depress the required temperature of a given decarbonation reaction (e.g., Ferry 1976, 2016; Kerrick 1977; Tracy et al.1983; Ague 2002; Penniston-Dorland and Ferry 2006). This can be observed in zones of enhanced decarbonation around fluid conduits, as shown in Figure 2c. Classic studies in the metamorphic belts of the Appalachian Mountains were among the first to demonstrate that fluid infiltration was essential for driving reactions and releasing $\mathrm{CO}_{2}$ (e.g., Ferry 1978, 1980; Rumble et al. 1982; Tracy et al. 1983).

As a demonstration, we calculate the $P-T$ conditions of reaction 2 . Figure 4 is a $P-T$ phase diagram showing the mineral assemblage that is stable at a given $P-T$ condition and fluid composition. When the $X_{\mathrm{CO}_{2}}$ (the mole fraction of $\mathrm{CO}_{2}$ ) in an $\mathrm{H}_{2} \mathrm{O}-\mathrm{CO}_{2}$ fluid is low, the reaction can occur at a much lower temperature. For example, at $0.2 \mathrm{GPa}$ the reaction occurs at $\sim 350{ }^{\circ} \mathrm{C}$ when $X_{\mathrm{CO}_{2}}=0.001$ and $\sim 700{ }^{\circ} \mathrm{C}$ when $X_{\mathrm{CO}_{2}}=1.0$ (Fig. 4).

This effect has two important implications. First, a rock that is metamorphosed in the presence of a water-bearing fluid can release over $500 \%$ more $\mathrm{CO}_{2}$ than the metamorphism of the same rock in a closed system at the same pressure and temperature (Stewart and Ague 2018). This enhanced decarbonation could ultimately result in a greater concentration of $\mathrm{CO}_{2}$ in the atmosphere and a correspondingly higher global surface temperature. Second, $\mathrm{CO}_{2}$ generated by infiltration is automatically released into a regional fluid flow system that provides the mechanism for transporting evolved $\mathrm{CO}_{2}$ from the deep crust to the atmosphere and hydrosphere.

\section{DiSCUSSION: CARBON FLUXES AND PLANETARY HABITABILITY}

Carbonation/decarbonation reactions play a vital role in carbon transfer on Earth. To understand how these reactions relate to planetary habitability, we must consider how different processes interact and balance through the long-term (geologic) carbon cycle. A great deal of the work done by geochemists focuses on constraining the magnitudes of major geologic carbon fluxes. These fluxes are broadly divided into sources (inputs into the ocean-atmosphere system) and sinks (outputs from the oceanatmosphere system). Thus, decarbonation reactions are sources of atmospheric $\mathrm{CO}_{2}$, and carbonation reactions are sinks (Fig. 5).

\section{Carbonation reaction fluxes}

It is generally agreed that the primary long-term sink of $\mathrm{CO}_{2}$ from the ocean-atmosphere system is the precipitation of carbonate rocks using alkalinity derived from silicate weathering (the Urey reactions). The continental silicate weathering flux can be estimated from measurements of river discharge, although on a very heterogeneous planet there are many complexities to consider. Nevertheless, continental silicate weathering is estimated, with reasonable uncertainty, to consume $\sim 11.5$ to $23 \mathrm{Tmol} \mathrm{CO}_{2}$ $\mathrm{yr}^{-1}$ (e.g., Gaillardet et al. 1999 and references therein).

The marine silicate weathering flux is less studied. One estimate of $\mathrm{CO}_{2}$ drawdown resulting from chemical weathering of deep-sea sediments is $\sim 5$ to $\sim 20 \mathrm{Tmol} \mathrm{CO}_{2} \mathrm{yr}^{-1}$, comparable in magnitude to the continental flux (Wallmann et al. 2008). Off-axis carbonation of basaltic oceanic crust may provide an additional sink of $\sim 0.2$ to $\sim 3.7 \mathrm{Tmol} \mathrm{CO}_{2} \mathrm{yr}^{-1}$ (e.g., Coogan and Gillis 2018 and references therein). However, reverse weathering recycles some $\mathrm{CO}_{2}$ back into the surface environment, effectively acting as a source of $\sim 0.5$ to $\sim 1.25 \mathrm{Tmol} \mathrm{CO}_{2} \mathrm{yr}^{-1}$ (Isson and Planavsky 2018).

\section{Decarbonation reaction fluxes}

Earth's major decarbonation reaction fluxes are the result of metamorphic outgassing reactions in continental collisions, subduction zones, and contact metamorphic aureoles. Metamorphism in continental rifts is less well-studied, but it may also make a significant contribution.

Metamorphic outgassing in continental collisions has primarily been studied at the regional scale. As shown by Stewart and Ague (2018), multiple estimates from ancient and modern mountain belts converge on an area-normalized flux of $\sim 0.5 \times$ $10^{6}$ to $\sim 7 \times 10^{6}$ moles $\mathrm{CO}_{2} \mathrm{~km}^{-2} \mathrm{yr}^{-1}$ (Kerrick and Caldeira 1998; Chiodini et al. 2000; Becker et al. 2008; Skelton 2011). These estimates are derived from independent, quite disparate methods, ranging from thermodynamic modeling of metacarbonate rocks in the Appalachians (Stewart and Ague 2018) to modern direct measurements of $\mathrm{CO}_{2}$ escaping from springs in the Himalayas and Italian Apennines (Chiodini et al. 2000; Becker et al. 2008). The agreement between estimates from deeply exhumed rocks and measurements at Earth's surface suggests that most devolatilized $\mathrm{CO}_{2}$ is ultimately released to the ocean-atmosphere system. We can multiply this areal flux estimate by the area of active continental collision for a rough global collisional metamorphic flux. The present area, dominated by the Himalayas with the area $\sim 7.5 \times 10^{5} \mathrm{~km}^{2}$ (Becker et al. 2008), is estimated on the order 


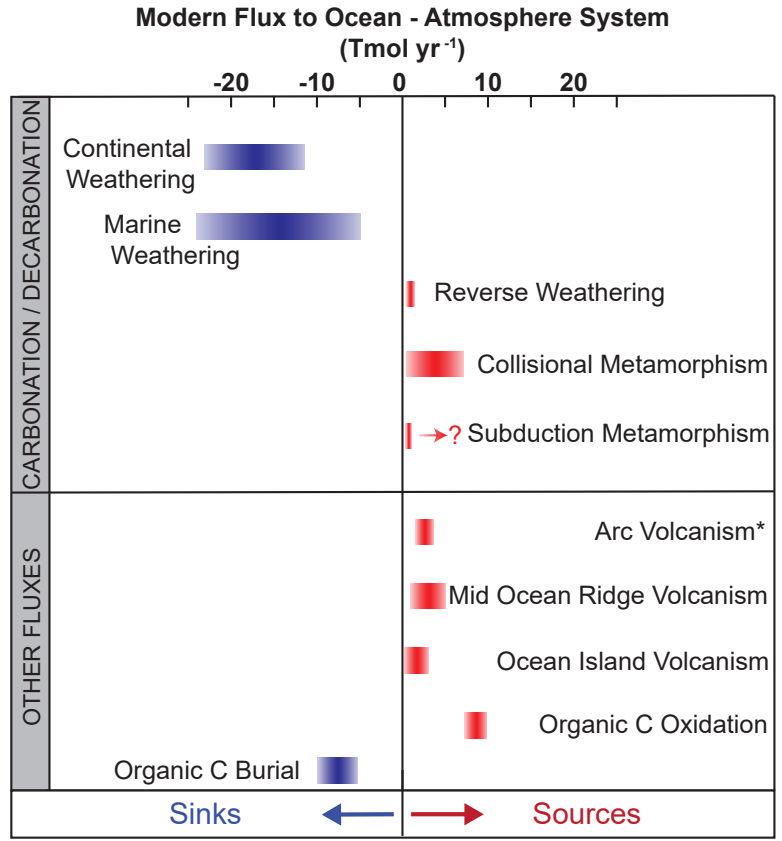

FIGURE 5. Estimates of modern $\mathrm{CO}_{2}$ fluxes to the ocean-atmosphere system. Error bars indicate a range of possible values, not necessarily a normal distribution. * Note that the flux from Arc Volcanism includes some contribution from decarbonation of subducting slabs; in fact, slab decarbonation could account for the vast majority of the arc volcanic flux. Arc magmas may also incorporate partially melted carbonate lithologies and drive contact metamorphism in adjacent rocks.

of $\sim 10^{6} \mathrm{~km}^{2}$. The resultant estimated global flux is $\sim 0.5$ to $\sim 7$ Tmol $\mathrm{CO}_{2} \mathrm{yr}^{-1}$, but note that this value is not constant through geologic time (Fig. 3).

Estimates of metamorphic degassing fluxes at subduction zones also cover a considerable range. In their compilation, Kelemen and Manning (2015) estimate $\sim 0.3$ to $\sim 4.9 \mathrm{Tmol} \mathrm{CO}_{2} \mathrm{yr}^{-1}$ are released from the slab via metamorphic reaction and dissolution. This estimate in itself carries significant uncertainties, largely due to uncertainties in the degree and nature of fluid infiltration during metamorphism. Closed-system calculations predict that the majority of subducted carbon is not released (e.g., the negligible flux estimate from Kerrick and Connolly 2001). Models that allow for fluid infiltration predict more decarbonation (e.g., 0.35 to $3.12 \mathrm{Tmol} \mathrm{CO}_{2} \mathrm{yr}^{-1}$, Gorman et al. 2006), with intermediate fluxes also suggested (Cook-Kollars et al. 2014). Carbonate dissolution, only recently identified in subduction zones (e.g., Ague and Nicolescu 2014), could significantly increase these estimates.

In addition, it is highly uncertain what proportion of the devolatilized $\mathrm{CO}_{2}$ makes it to the atmosphere (either escaping through arc volcanoes or through its own diffuse outgassing) and how much is stored in the overlying lithosphere. Kelemen and Manning (2015) report a diffuse outgassing flux of $\sim 0.3$ to $1.0 \mathrm{Tmol} \mathrm{CO}_{2} \mathrm{yr}^{-1}$, but emphasize that they suspect it might actually be much larger.

Contact metamorphism, though spatially limited, has the potential to contribute large quantities of $\mathrm{CO}_{2}$. High temperaturelow pressure conditions can drive decarbonation reactions such as reaction 2 particularly efficiently. Contact metamorphism, in particular, may occur overshort timescales (e.g., Lyubetskaya and Ague 2010). The total contact metamorphic flux is difficult to estimate, but some researchers suggest it has played an important role in changing climate conditions through Earth history (e.g., Lee et al. 2013).

Although our discussion of $\mathrm{CO}_{2}$ sources is focused on decarbonation reaction fluxes, we can compare their magnitudes to other important $\mathrm{CO}_{2}$-generating fluxes. Typical estimates for the three major volcanic fluxes in the modern era are as follows: $\sim 1.5$ to $\sim 3.1 \mathrm{Tmol} \mathrm{CO}_{2} \mathrm{yr}^{-1}$ for arc volcanism (Marty and Tolstikhin 1998; Hilton et al. 2002; Dasgupta and Hirschmann 2010), 0.5 to $\sim 5.0 \mathrm{Tmol} \mathrm{CO}_{2} \mathrm{yr}^{-1}$ for mid-ocean ridge volcanism (Marty and Tolstikhin 1998; Dasgupta and Hirschmann 2006, 2010; Le Voyer et al. 2019) and $\sim 0.12$ to $\sim 3 \mathrm{Tmol} \mathrm{CO}_{2} \mathrm{yr}^{-1}$ from ocean island volcanoes (Marty and Tolstikhin 1998; Dasgupta and Hirschmann 2010). Volcanogenic $\mathrm{CO}_{2}$ may also reach the atmosphere via diffuse outgassing (Allard 1992). Organic carbon weathering is somewhat larger at $\sim 7.5$ to $\sim 10 \mathrm{Tmol} \mathrm{CO}_{2} \mathrm{yr}^{-1}$ (Holland 1978; Kump and Arthur 1999), but is largely balanced out by the organic carbon burial flux of $\sim 5.3$ to $\sim 10 \mathrm{Tmol} \mathrm{CO}_{2}$ $\mathrm{yr}^{-1}$ (Berner 1982; Kump and Arthur 1999). Thus, metamorphic outgassing fluxes are of the same order of magnitude as other major source fluxes. Metamorphic decarbonation reactions are therefore more important to the net global carbon budget than is often appreciated (Fig. 5).

\section{Earth's habitability and the need for balance}

It has been commonly argued that surface temperatures on Earth have been remarkably stable for billions of years. Sedimentary rocks record the presence of liquid water since at least $\sim 3.8$ billion years ago (Lowe 1980), which requires global surface temperatures to remain between 0 and $100{ }^{\circ} \mathrm{C}$ for a vast amount of time. Some researchers suggest there is evidence for liquid water even earlier (e.g., 4.3 billion years ago by Mojzsis et al. 2001; 4.4 billion years ago by Wilde et al. 2001).

In an apparent contradiction, the Sun has been increasing in luminosity and, therefore, supplying more heat to Earth over time. It is estimated that the sun's luminosity in early Earth history was only $\sim 70 \%$ of the modern intensity (Sagan and Mullen 1972); thus, one might expect Earth's temperature to have changed markedly in response to these changes in incoming solar energy. As Sagan and Mullen pointed out in 1972, an Earth with today's atmospheric composition would have been completely frozen (below $0{ }^{\circ} \mathrm{C}$ ) until about 2 billion years ago. This is at odds with geologic evidence for a warm climate early in Earth's history (e.g., Knauth and Epstein 1976). This logical problem has been referred to as the "Faint Young Sun Paradox," and remains the subject of active debate today (see Kasting 2010). However, one simple solution to this paradox lies in Earth's atmosphere. A more carbon-rich atmosphere would result in a more intense greenhouse effect and, perhaps, higher surface temperatures even with a weaker sun (Owen et al. 1979; Walker et al. 1981).

On the other side of the spectrum, Earth has likewise never become too hot since the emergence of the earliest life forms. If $\mathrm{CO}_{2}$ concentrations became extremely high, the temperature could skyrocket and the oceans could boil. Thus, we find ourselves on a type of Goldilocks planet: $\mathrm{CO}_{2}$ concentrations never get excessively high or excessively low, but, within relatively 
narrow limits, they remain just right.

In their classic analysis, Berner and Caldeira (1997) argue that this cannot be a coincidence. On long timescales, the amount of $\mathrm{CO}_{2}$ added to the atmosphere must equal the amount of $\mathrm{CO}_{2}$ removed. Without this balance, atmospheric $\mathrm{CO}_{2}$ concentrations would run-away, resulting in an extreme hot house or ice house climates. Berner and Caldeira (1997) demonstrate this with a simple calculation of the effect of only small (25\%) imbalances between $\mathrm{CO}_{2}$ inputs and outputs (Fig. 6).

Major $\mathrm{CO}_{2}$ fluxes have been changing throughout Earth history. To maintain balance, then, some stabilizing mechanism or negative feedback must be in place, ensuring that inputs and outputs eventually reach a steady state. By simply summing modern flux estimates (Fig. 5), we find that the predicted net change of the atmospheric reservoir is between $\sim-45$ and $\sim+11$ Tmol $\mathrm{CO}_{2} \mathrm{yr}^{-1}$. This estimate does overlap the necessary value of zero net change, but the large uncertainty is obvious. Nonetheless, we can outline several different end-member Earth states. With high weathering rate estimates (e.g., with large marine weathering fluxes; Wallmann et al. 2008; Coogan and Gillis 2018) upper-end-member outgassing rates are required. High amounts of reverse weathering (e.g., Rahman et al. 2017) could also help balance high silicate weathering rates with outgassing estimates. In contrast, in the traditional view-where silicate weathering occurs predominantly in continental settings — only the lowest outgassing fluxes allow the modern Earth to be close to a steady state.

The continental silicate weathering feedback. The silicate weathering feedback is the most prominent suggested mechanism for stabilizing the global carbon cycle. It was first proposed by Walker et al. (1981) and stated that the rate of continental silicate weathering and resultant carbonate precipitation (whether abiotic or biologically mediated) speeds up at higher temperatures and higher $\mathrm{CO}_{2}$ concentrations. Recall that silicate weathering is the primary pathway for removing $\mathrm{CO}_{2}$ from the atmosphere, thus this constitutes negative feedback: rising $\mathrm{CO}_{2}$ concentrations drive increasing global temperatures and increased silicate weathering that, in turn, draws more $\mathrm{CO}_{2}$ out of the atmosphere, lowering $\mathrm{CO}_{2}$ concentrations and global temperature.

This does not imply that $\mathrm{CO}_{2}$ concentrations are essentially fixed throughout time. If $\mathrm{CO}_{2}$ input fluxes are permanently doubled, the atmospheric $\mathrm{CO}_{2}$ and temperature will not return to previous values as a result of this feedback. Rather, the concentration of $\mathrm{CO}_{2}$ and global temperature will increase until the $\mathrm{CO}_{2}$ output flux - silicate weathering - again matches the inputs. The system will then reach a new steady state such that the concentration of $\mathrm{CO}_{2}$ and the temperature are higher than before, but they are stable. This also implies that there will be periods of Earth history when inputs and outputs are temporarily imbalanced. For example, Dutkiewicz et al. (2018) suggest that Cenozoic carbonation has outpaced solid earth decarbonation, causing a global cooling trend. Recall, also, that the "Faint Young Sun Paradox" of Sagan and Mullen (1972) requires that the atmosphere has systematically lost $\mathrm{CO}_{2}$ over billions of years. As a consequence, feedback does not guarantee fixed temperatures, but it prevents run-away warming or cooling trends.

The nature of the relationship between temperature and silicate weathering remains the subject of vigorous debate. Some

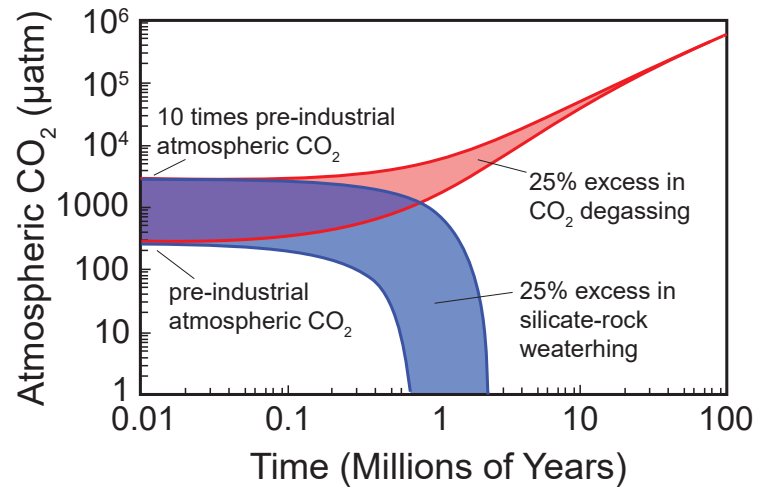

FIGURE 6. Predicted atmospheric $\mathrm{CO}_{2}$ concentrations in an Earth system where $\mathrm{CO}_{2}$ sources and sinks do not balance, modified after Berner and Caldeira (1997). Regardless of starting $\mathrm{CO}_{2}$ concentration, a $25 \%$ excess in $\mathrm{CO}_{2}$ degassing (red curves) or a $25 \%$ excess in silicate weathering (blue curves) result in a run-away atmospheric composition within $\sim 1$ million years.

have proposed that global surface temperatures exert direct control on silicate weathering through a simple temperaturedependent reaction rate. In laboratory experiments, the rate of chemical weathering of silicate minerals (e.g., reaction 1C) has been demonstrated to increase with increasing temperature (e.g., Lagache 1976; Brady and Carroll 1994), yet in field studies results are mixed. Edmond et al. (1995) report no evidence of increased chemical weathering at higher temperatures, while Meybeck (1979) finds a significant relationship. This work is complicated by the correlations between, for example, river runoff and temperature that exist in nature.

Another possible mechanism relates $\mathrm{CO}_{2}$ to chemical weathering directly: as atmospheric $\mathrm{CO}_{2}$ concentrations increase, more $\mathrm{CO}_{2}$ will be dissolved in water to from carbonic acid. This more acidic surface environment could also contribute to faster chemical weathering of silicate minerals (e.g., Berg and Banwart 2000). This factor is likely more important prior to the rise of land plants and the onset of extensive soil respiration.

Most research today focuses on indirect relationships between temperature and silicate weathering. In particular, higher temperatures drive increased global precipitation rates and increased river runoff (Holland 1978; Manabe and Stouffer 1993). Therefore, many models suggest that it is primarily this invigoration of the water cycle that enhances silicate weathering and $\mathrm{CO}_{2}$ drawdown (Berner and Berner 1997; Maher and Chamberlain 2014). Teasing out the influence of temperature, precipitation, or other factors can be extremely challenging in such complex systems, but modern statistical techniques (e.g., machine learning) could be an effective means to probe the factors driving the silicate weathering feedback.

Marine weathering feedback. Because weathering of continental material has historically been considered as the primary contribution to global silicate weathering, it has also been assumed to be the source of the associated negative feedback. However, recent studies have demonstrated that seafloor weathering and carbonation may offer an additional, complementary negative feedback. The general idea is the same: rising $\mathrm{CO}_{2}$ concentrations 
and global temperatures increase the rate of marine weathering, thereby drawing down more $\mathrm{CO}_{2}$ and stabilizing the system. Indeed, off-axis hydrothermal alteration of the basaltic crust is enhanced at higher temperatures (Coogan and Dosso 2015). The rate of silicate mineral dissolution will be significantly faster when the ocean bottom water temperature is elevated. On the other hand, it has been suggested that chemical weathering of marine anoxic sediments is largely independent of temperature (Wallmann et al. 2008). Importantly, $\mathrm{CO}_{2}$ that is stored in the oceanic crust may, in the future, contribute to a metamorphic decarbonation flux when it is inevitably subducted (Fig. 1).

Reverse weathering feedback. It was recently proposed that reverse weathering can act as important stabilizing feedback for carbon cycling (Isson and Planavsky 2018). In this case, increasing atmospheric $\mathrm{CO}_{2}$ makes the ocean more acidic, reducing the amount of clay formation, and thus $\mathrm{CO}_{2}$ release, from reverse weathering. This, in turn, lowers atmospheric $\mathrm{CO}_{2}$, pushing ocean water $\mathrm{pH}$ back toward less acidic values. Today this feedback is less effective - clay formation is limited by the availability of $\mathrm{SiO}_{2}$ dissolved in the ocean. There is evidence, however, that this process was much more important early in Earth's history. Prior to the Cambrian Period ( 542 million years ago) oceanic silica concentrations were much higher. This would allow for more reverse weathering and, perhaps, enhanced efficiency of a reverse weathering negative feedback (Isson and Planavsky 2018).

\section{IMPLICATIONS}

\section{Future work}

Major gaps remain in our understanding of global carbonation/ decarbonation reactions. More work is needed on constraining the magnitude of the various carbon fluxes and how they balance one another throughout time. One area of particular uncertainty is the fate of subducted carbon. As of today, it is unknown whether most of the carbonate minerals in the oceanic crust are ultimately delivered to the deep mantle, or if they devolatilize during subduction. And for the $\mathrm{CO}_{2}$ that does escape the downgoing slab, is most of it ultimately released to the atmosphere, or is it stored in the subarc lithosphere (Kelemen and Manning 2015)? Observations made in ancient and modern subduction zones in concert with constraints from experiments and numerical modeling must begin to answer these questions if we are to make progress in a global understanding of carbon mobility.

Another significant uncertainty is the strength of the silicate weathering feedback. This feedback is not perfectly efficient - the Earth has swung between the hot house and ice house conditions many times in the past (e.g., Royer et al. 2004). In fact, the strength of the feedback is certainly not fixed. We see evidence for periods of reduced and enhanced feedback efficiency in the geologic record (e.g., Caves et al. 2016). Nevertheless, the ability to constrain the magnitude of the effect of silicate weathering in ancient and modern Earth systems will allow us to make more accurate calculations of past and future climate. Both theoretical (e.g., Winnick and Maher 2018) and observational approaches could provide valuable new insights.

There is limited work on the behavior of carbonate minerals at high pressures. For example, recent work suggests carbon in subduction zones is hosted in the minerals dolomite and magnesite (Tao et al. 2018), yet experimental constraints on their solubilities at these conditions are lacking. Recent theoretical work is addressing the issue (e.g., Sverjensky et al. 2014; Connolly and Galvez 2018), and should be supplemented by a new generation of experimental data.

\section{Exoplanet habitability}

Each of the processes discussed has important implications in the study of distant exoplanets and our search for other habitable worlds. The presence of a silicate weathering feedback, for example, will significantly increase the size of the "habitable zone" around a given star - the range of planetary distances from the star that falls within a habitable temperature range (Kasting et al. 1993). The balance between continental and marine weathering feedbacks is also important. If marine weathering is not a significant negative feedback mechanism, then we would not expect planets that are mostly ocean ("water worlds") to have a stable, habitable climate (Abbot et al. 2012). If, on the other hand, marine weathering is strongly temperature dependent, these worlds would be more likely to sustain life. The presence of volcanism and/or plate tectonics could also have profound effects on an exoplanet's carbon cycle and potential habitability (e.g., Sleep and Zahnle 2001). Studying these processes on Earth may lead to better predictions of which distant planets might be hospitable to life.

\section{Carbonation reactions and anthropogenic climate change}

Since the industrial revolution, Earth's global carbon cycle has been subject to a fast and massive perturbation, evidently unequaled in geologic history. Through the burning of fossil fuels, deforestation, and other human activity, $\sim 795 \mathrm{Tmol} \mathrm{CO}_{2}$ are added to the ocean-atmosphere system every year (Friedlingstein et al. 2010). This is more than 100 times greater than the global volcanic $\mathrm{CO}_{2}$ flux or, as Gerlach (2011) notes, equivalent to about 9500 Kilauea volcanoes. One could, perhaps, take comfort in the knowledge that the natural geologic carbon cycle can eventually stabilize global temperatures, but most will consider a lag time of about 1 million years unacceptable. With this in mind, some researchers are attempting to harness and accelerate the power of silicate weathering to counteract human-driven climate change in our lifetimes (O'Connor et al. 2001; Lackner 2003; Park and Fan 2004; Kelemen and Matter 2008; Lal 2008; Wilson et al. 2009; Lechat et al. 2016; Power et al. 2016; Kelemen et al. 2018).

In many cases, ultramafic rocks are used. These rocks are composed of Mg-rich silicate minerals that are particularly unstable at Earth's surface, which facilitates dissolution (like reaction $1 \mathrm{C}$ ) and subsequent carbonation. In some cases, these rocks are merely ground up and exposed at Earth's surface to undergo natural reaction with the atmosphere (e.g., Lechat et al. 2016), while other studies consider more active processes, such as pumping a $\mathrm{CO}_{2}$-rich fluid through the rocks (this is more similar to off-axis hydrothermal alteration; e.g., Park and Fan 2004; Matter et al. 2016). In either case, understanding natural geologic carbonation reactions have the potential to inform future work on carbon sequestration and contribute to the continued habitability of planet Earth. 


\section{ACKNOWLEDGMENTS}

We thank the Deep Carbon Observatory and specifically the Reservoirs and Fluxes Community and the attendees of the 2018 "The Earth in Five Reactions" workshop for their support of this work. We are grateful for insightful discussions with G.E. Bebout, R.A. Berner, O. Beyssac, A.V. Brovarone, C.P. Chamberlain, D.A.D. Evans, M.E. Galvez, B. Marty, F. Piccoli, D. Rumble, D.M. Rye, M. Tian, and J.L.M. van Haren. This work also benefits from constructive reviews by A.D.L. Skelton and an anonymous reviewer.

\section{FUNDING}

Funding provided by the National Science Foundation (EAR-1650329 to J.J.A.) and Yale University is gratefully acknowledged.

\section{REFERENCES CITED}

Abbot, D.S., Cowan, N.B., and Ciesla, F.J. (2012) Indication of insensitivity of planetary weathering behavior and habitable zone to surface land fraction. The Astrophysical Journal, 756(2), 178.

Ague, J.J. (2002) Gradients in fluid composition across metacarbonate layers of the Wepawaug Schist, Connecticut, USA. Contributions to Mineralogy and Petrology, 143(1), 38-55.

- (2003) Fluid infiltration and transport of major, minor, and trace elements during regional metamorphism of carbonate rocks, Wepawaug Schist, Connecticut, USA. American Journal of Science, 303(9), 753-816.

Ague, J.J., and Nicolescu, S. (2014) Carbon dioxide released from subduction zones by fluid-mediated reactions. Nature Geoscience, 7(5), 355.

Allard, P. (1992) Diffuse degassing of carbon dioxide through volcanic systems: observed facts and implications. Report, Geological Survey of Japan, 7-11.

Amiotte Suchet, P., and Probst, J.L. (1995) A global model for present-day atmospheric: Soil $\mathrm{CO}_{2}$ consumption by chemical erosion of continental rocks $\left(\mathrm{GEM}-\mathrm{CO}_{2}\right.$ ). Tellus, 47B, 273-280.

Archer, D. (2010) The Global Carbon Cycle, 205 pp., Princeton University Press. Arrhenius, S. (1915) Quantitative laws in biological chemistry (Vol. 1915). G. Bell.

Becker, J.A., Bickle, M.J., Galy, A., and Holland, T.J. (2008) Himalayan metamorphic $\mathrm{CO}_{2}$ fluxes: Quantitative constraints from hydrothermal springs. Earth and Planetary Science Letters, 265(3-4), 616-629.

Berg, A., and Banwart, S.A. (2000) Carbon dioxide mediated dissolution of Ca-feldspar: implications for silicate weathering. Chemical Geology, 163(1-4), 25-42.

Berner, R.A. (1982) Burial of organic carbon and pyrite sulfur in the modern ocean: its geochemical and environmental significance. American Journal of Science, 282, 451-473.

- (1995) AG Högbom and the development of the concept of the geochemical carbon cycle. American Journal of Science, 295(5), 491-495.

Berner, R.A., and Berner, E.K. (1997) Silicate weathering and climate. In W.F. Ruddiman, Ed., Tectonic Uplift and Climate Change, p. 353-365. Springer.

Berner, R.A., and Caldeira, K. (1997) The need for mass balance and feedback in the geochemical carbon cycle. Geology, 25(10), 955-956.

Berner, R.A., Lasaga, A.C., and Garrels, R.M. (1983) The carbonate-silicate geochemical cycle and its effect on atmospheric carbon dioxide over the past 100 million years. American Journal of Science, 283, 641-683.

Bowen, N.L. (1940) Progressive metamorphism of siliceous limestone and dolomite. The Journal of Geology, 48(3), 225-274.

Brady, P.V., and Carroll, S.A. (1994) Direct effects of $\mathrm{CO}_{2}$ and temperature on silicate weathering: Possible implications for climate control. Geochimica et Cosmochimica Acta, 58(7), 1853-1856.

Brady, P.V., and Gíslason, S.R. (1997) Seafloor weathering controls on atmospheric $\mathrm{CO}_{2}$ and global climate. Geochimica et Cosmochimica Acta, 61(5), 965-973.

Burgess, S.D., Muirhead, J.D., and Bowring, S.A. (2017) Initial pulse of Siberian Traps sills as the trigger of the end-Permian mass extinction. Nature Communications, 8(1), 164.

Burke, K., Dewey, J.F., and Kidd, W.S.F. (1977) World distribution of sutures - the sites of former oceans. Tectonophysics, 40(1-2), 69-99.

Campbell, K.A., Farmer, J.D., and Des Marais, D. (2002) Ancient hydrocarbon seeps from the Mesozoic convergent margin of California: carbonate geochemistry, fluids and palaeoenvironments. Geofluids, 2(2), 63-94.

Caves, J.K., Jost, A.B., Lau, K.V., and Maher, K. (2016) Cenozoic carbon cycle imbalances and a variable weathering feedback. Earth and Planetary Science Letters, 450, 152-163.

Chiodini, G., Frondini, F., Cardellini, C., Parello, F., and Peruzzi, L. (2000) Rate of diffuse carbon dioxide Earth degassing estimated from carbon balance of regional aquifers: the case of central Apennine, Italy. Journal of Geophysical Research: Solid Earth, 105(B4), 8423-8434.

Connolly, J.A., and Galvez, M.E. (2018) Electrolytic fluid speciation by Gibbs energy minimization and implications for subduction zone mass transfer. Earth and Planetary Science Letters, 501, 90-102.

Coogan, L.A., and Dosso, S.E. (2015) Alteration of ocean crust provides a strong temperature dependent feedback on the geological carbon cycle and is a primary driver of the Sr-isotopic composition of seawater. Earth and Planetary
Science Letters, $415,38-46$

Coogan, L.A., and Gillis, K.M. (2013) Evidence that low-temperature oceanic hydrothermal systems play an important role in the silicate-carbonate weathering cycle and long-term climate regulation. Geochemistry, Geophysics, Geosystems, 14(6), 1771-1786.

(2018) Low-temperature alteration of the seafloor: Impacts on ocean chemistry. Annual Review of Earth and Planetary Sciences, 46, 21-45.

Cook-Kollars, J., Bebout, G.E., Collins, N.C., Angiboust, S., and Agard, P. (2014) Subduction zone metamorphic pathway for deep carbon cycling: I. Evidence from HP/UHP metasedimentary rocks, Italian Alps. Chemical Geology, 386, $31-48$.

Dasgupta, R., and Hirschmann, M.M. (2006) Melting in the Earth's deep upper mantle caused by carbon dioxide. Nature, 440, 659 .

(2010) The deep carbon cycle and melting in Earth's interior. Earth and Planetary Science Letters, 298(1-2), 1-13.

de Capitani, C., and Petrakakis, K. (2010) The computation of equilibrium assemblage diagrams with Theriak/Domino software. American Mineralogist, 95, 1006-1016.

Delesse, A. (1858) Etudes sur la métamorphisme des roches. Annales de Mines.

Dessert, C., Dupré, B., Gaillardet, J., François, L.M., and Allegre, C.J. (2003) Basalt weathering laws and the impact of basalt weathering on the global carbon cycle. Chemical Geology, 202(3-4), 257-273.

Dutkiewicz, A., Müller, R.D., Cannon, J., Vaughan, S., and Zahirovic, S. (2018) Sequestration and subduction of deep-sea carbonate in the global ocean since the Early Cretaceous. Geology, 47(1), 91-94.

Edmond, J.M., Palmer, M.R., Measures, C.I., Grant, B., and Stallard, R.F. (1995) The fluvial geochemistry and denudation rate of the Guayana Shield in Venezuela, Colombia, and Brazil. Geochimica et Cosmochimica Acta, 59(16), $3301-3325$.

Evans, B.W., and Trommsdorff, V. (1974) Stability of enstatite + talc and $\mathrm{CO}_{2^{-}}$ metasomatism of metaperidotite, Val d'Efra, Lepontine Alps. American Journal of Science, 274(3), 274-296.

Falk, E.S., and Kelemen, P.B. (2015) Geochemistry and petrology of listvenite in the Samail ophiolite, Sultanate of Oman: complete carbonation of peridotite during ophiolite emplacement. Geochimica et Cosmochimica Acta, 160, 70-90.

Ferry, J.M. (1976) Metamorphism of calcareous sediments in the WatervilleVassalboro area, South-central Maine; mineral reactions and graphical analysis. American Journal of Science, 276(7), 841-882.

(1978) Fluid interaction between granite and sediment during metamorphism, south-central Maine. American Journal of Science, 278(8), 1025-1056. (1980) A case study of the amount and distribution of heat and fluid during metamorphism. Contributions to Mineralogy and Petrology, 71(4), 373-385. (1988) Infiltration-driven metamorphism in northern New England, USA. Journal of Petrology, 29(6), 1121-1159.

- (1995) Fluid flow during contact metamorphism of ophicarbonate rocks in the Bergell aureole, Val Malenco, Italian Alps. Journal of Petrology, 36(4), 1039-1053.

(2000) Patterns of mineral occurrence in metamorphic rocks. American Mineralogist, 85, 1573-1588.

(2016) Fluids in the crust during regional metamorphism: Forty years in the Waterville limestone. American Mineralogist, 101, 500-517.

Ferry, J.M., Rumble, D., Wing, B.A., and Penniston-Dorland, S.C. (2005) A new interpretation of centimetre-scale variations in the progress of infiltrationdriven metamorphic reactions: Case study of carbonated Metaperidotite, Val d'Efra, Central Alps, Switzerland. Journal of Petrology, 46(8), 1725-1746.

Frezzotti, M.L., Selverstone, J., Sharp, Z.D., and Compagnoni, R. (2011) Carbonate dissolution during subduction revealed by diamond-bearing rocks from the Alps. Nature Geoscience, 4(10), 703.

Friedlingstein, P., Houghton, R.A., Marland, G., Hackler, J., Boden, T.A., Conway, T.J., and Le Quere, C. (2010) Update on $\mathrm{CO}_{2}$ emissions. Nature Geoscience, 3(12), 811 .

Gaillardet, J., Dupré, B., Louvat, P., and Allegre, C.J. (1999) Global silicate weathering and $\mathrm{CO}_{2}$ consumption rates deduced from the chemistry of large rivers. Chemical Geology, 159(1-4), 3-30.

Ganino, C., and Arndt, N.T. (2009) Climate changes caused by degassing of sediments during the emplacement of large igneous provinces. Geology, 37(4), 323-326.

Garrels, R.M. (1965) Silica: Role in the buffering of natural waters. Science, 148(3666), 69.

Gerlach, T. (2011) Volcanic versus anthropogenic carbon dioxide. Eos, Transactions American Geophysical Union, 92(24), 201-202.

Gillis, K.M., and Coogan, L.A. (2011) Secular variation in carbon uptake into the ocean crust. Earth and Planetary Science Letters, 302(3), 385-392.

Goldschmidt, V.M. (1912) Die Gesetze der Gesteinsmetamorphose mit Beispielen aus der Geologie des Südlichen Norwegens (The laws of rock metamorphism with examples from the geology of southern Norway). Vi denskapsselskapets Skrifter. 1.

Gorman, P.J., Kerrick, D.M., and Connolly, J.A.D. (2006) Modeling open system metamorphic decarbonation of subducting slabs. Geochemistry, Geophysics, 
Geosystems, 7(4)

Greenwood, H.J. (1975) Buffering of pore fluids by metamorphic reactions. American Journal of Science, 275, 573-593.

Harker, R.I., and Tuttle, O.F. (1956) Experimental data on the $P_{\mathrm{CO}_{2}}-T$ curve for the reaction; calcite-quartz $\leftrightarrow$ wollastonite + carbon dioxide. American Journal of Science, 254(4), 239-256.

Hilton, D.R., Fischer, T.P., and Marty, B. (2002) Noble gases and volatile recycling at subduction zones. Reviews in Mineralogy and Geochemistry, 47, 319-370.

Högbom, A. (1894) Om sannolikheten för sekulära förändringar i atmosfärens kolsyrehalt (On the probability of secular variations of atmospheric carbon dioxide). Svensk kemisk tidskrift, 4, 169-177.

Holland, H.D. (1978) The Chemistry of the Atmosphere and Oceans. Wiley.

Holland, T.J.B., and Powell, R.T.J.B. (1998) An internally consistent thermodynamic data set for phases of petrological interest. Journal of Metamorphic Geology, 16(3), 309-343.

Isson, T.T., and Planavsky, N.J. (2018) Reverse weathering as a long-term stabilizer of marine $\mathrm{pH}$ and planetary climate. Nature, 560,471

Jenny, H. (1941) Factors of Soil Formation. McGraw-Hill

Kasting, J.F. (2010) Early Earth: Faint young Sun redux. Nature, 464, 687.

Kasting, J.F., Whitmire, D.P., and Reynolds, R.T. (1993) Habitable zones around main sequence stars. Icarus, 101(1), 108-128.

Kelemen, P.B., and Manning, C.E. (2015) Reevaluating carbon fluxes in subduction zones, what goes down, mostly comes up. Proceedings of the National Academy of Sciences 201507889.

Kelemen, P.B., and Matter, J.M. (2008) In situ carbonation of peridotite for $\mathrm{CO}_{2}$ storage. Proceedings of the National Academy of Sciences, 105, 17295-17300.

Kelemen, P.B., Matter, J., Streit, E.E., Rudge, J.F., Curry, W.B., and Blusztajn, J. (2011) Rates and mechanisms of mineral carbonation in peridotite: natural processes and recipes for enhanced, in situ $\mathrm{CO} 2$ capture and storage. Annual Review of Earth and Planetary Sciences, 39, 545-576.

Kelemen, P.B., Aines, R., Bennett, E., Benson, S.M., Carter, E., Coggon, J.A., and Godard, M. (2018) In situ carbon mineralization in ultramafic rocks: Natural processes and possible engineered methods. Energy Procedia, 146, 92-102.

Kennedy, W.Q. (1948) On the significance of thermal structure in the Scottish Highlands. Geological Magazine, 85(4), 229-234.

Kerrick, D.M. (1977) The genesis of zoned skarns in the Sierra Nevada, California. Journal of Petrology, 18(1), 144-181.

Kerrick, D.M., and Caldeira, K. (1998) Metamorphic $\mathrm{CO}_{2}$ degassing from orogenic belts. Chemical Geology, 145(3-4), 213-232.

Kerrick, D.M., and Connolly, J.A.D. (2001) Metamorphic devolatilization of subducted marine sediments and the transport of volatiles into the Earth's mantle. Nature, 411, 293.

Knauth, L.P., and Epstein, S. (1976) Hydrogen and oxygen isotope ratios in nodular and bedded cherts. Geochimica et Cosmochimica Acta, 40(9), 1095-1108.

Kump, L.R., and Arthur, M.A. (1999) Interpreting carbon-isotope excursions: carbonates and organic matter. Chemical Geology, 161(1-3), 181-198.

Lackner, K.S. (2003) A guide to $\mathrm{CO}_{2}$ sequestration. Science, 300(5626), 1677-1678.

Lagache, M. (1976) New data on the kinetics of the dissolution of alkali feldspars at $200{ }^{\circ} \mathrm{C}$ in $\mathrm{CO}_{2}$ charged water. Geochimica et Cosmochimica Acta, $40(2)$, $157-161$.

Lal, R. (2008) Carbon sequestration. Philosophical Transactions of the Royal Society of London B: Biological Sciences, 363, 815-830.

Le Voyer, M., Hauri, E.H., Cottrell, E., Kelley, K.A., Salters, V.J., Langmuir, C.H., and Füri, E. (2019) Carbon fluxes and primary magma $\mathrm{CO}_{2}$ contents along the global mid-ocean ridge system. Geochemistry, Geophysics, Geosystems, 20.

Lechat, K., Lemieux, J.M., Molson, J., Beaudoin, G., and Hébert, R. (2016) Field evidence of $\mathrm{CO}_{2}$ sequestration by mineral carbonation in ultramafic milling wastes, Thetford Mines, Canada. International Journal of Greenhouse Gas Control, 47, 110-121.

Lee, C.T.A., Shen, B., Slotnick, B.S., Liao, K., Dickens, G.R., Yokoyama, Y., and Schneider, T. (2013) Continental arc-island arc fluctuations, growth of crustal carbonates, and long-term climate change. Geosphere, 9(1), 21-36.

Li, J., Redfern, S.T.A., and Giovannelli, D. (2019) Introduction: Deep carbon cycle through five reactions. American Mineralogist, 104, 465-467.

Loughnan, F.C. (1969) Chemical Weathering of the Silicate Minerals. Elsevier, New York, $154 \mathrm{pp}$.

Lowe, D.R. (1980) Archean sedimentation. Annual Review of Earth and Planetary Sciences, 8(1), 145-167.

Lyubetskaya, T., and Ague, J.J. (2010) Modeling metamorphism in collisional orogens intruded by magmas: I. Thermal evolution. American Journal of Science, 310(6), 427-458.

Mackenzie, F.T., and Garrels, R.M. (1966) Chemical mass balance between rivers and oceans. American Journal of Science, 264(7), 507-525.

Maher, K., and Chamberlain, C.P. (2014) Hydrologic regulation of chemical weathering and the geologic carbon cycle. Science, 343, 1502-1504.

Manabe, S., and Stouffer, R.J. (1993) Century-scale effects of increased atmospheric $\mathrm{CO}_{2}$ on the ocean-atmosphere system. Nature, $364,215$.

Marty, B., and Tolstikhin, I.N. (1998) $\mathrm{CO}_{2}$ fluxes from mid-ocean ridges, arcs and plumes. Chemical Geology, 145(3), 233-248.

Mason, E., Edmonds, M., and Turchyn, A.V. (2017) Remobilization of crustal carbon may dominate volcanic arc emissions. Science, 357, 290-294.

Matter, J.M., Stute, M., Snæbjörnsdottir, S.Ó., Oelkers, E.H., Gislason, S.R. Aradottir, E.S., and Axelsson, G. (2016) Rapid carbon mineralization for permanent disposal of anthropogenic carbon dioxide emissions. Science, $352,1312-1314$

Meybeck, M. (1979) Concentrations des eaux fluviales en éléments majeurs et apports en solution aux oceans (Concentrations of major elements in fluvial waters and solutions in the oceans), Revue de Géologie Dynamique et de Géographie Physique., 21, 215-246.

Miyashiro, A. (1972) Metamorphism and related magmatism in plate tectonics. American Journal of Science, 272(7), 629-656.

Mojzsis, S.J., Harrison, T.M., and Pidgeon, R.T. (2001) Oxygen-isotope evidence from ancient zircons for liquid water at the Earth's surface 4,300 Myrs ago. Nature, 409, 178

Nabelek, P.I., Bédard, J.H., and Rainbird, R.H. (2014) Numerical constraints on degassing of metamorphic $\mathrm{CO}_{2}$ during the Neoproterozoic Franklin large igneous event. Arctic Canada Bulletin, 126(5-6), 759-772.

O'Connor, W.K., Dahlin, D.C., Nilsen, D.N., Rush, G.E., Walters, R.P., and Turner, P.C. (2001) Carbon dioxide sequestration by direct mineral carbonation: results from recent studies and current status. Albany Research Center (ARC), Albany, Oregon, No. DOE/ARC-2001-029.

Orme, D.A. (2015) Basin evolution and exhumation of the Xigaze forearc and Indus-Yarlung suture zone, Tibet. Ph.D. thesis, The University of Arizona.

Owen, T., Cess, R.D., and Ramanathan, V. (1979) Enhanced $\mathrm{CO}_{2}$ greenhouse to compensate for reduced solar luminosity on early Earth. Nature, 277, 640.

Pan, D., and Galli, G. (2016) The fate of carbon dioxide in water-rich fluids under extreme conditions. Science Advances 2(10), e1601278

Park, A.H.A., and Fan, L.S. (2004) $\mathrm{CO}_{2}$ mineral sequestration: physically activated dissolution of serpentine and $\mathrm{pH}$ swing process. Chemical Engineering Science, 59(22-23), 5241-5247.

Penniston-Dorland, S.C., and Ferry, J.M. (2006) Development of spatial variations in reaction progress during regional metamorphism of micaceous carbonate rocks, northern New England. American Journal of Science, 306(7), 475-524.

Piccoli, F., Brovarone, A.V., Beyssac, O., Martinez, I., Ague, J.J., and Chaduteau, C. (2016) Carbonation by fluid-rock interactions at high-pressure conditions: implications for carbon cycling in subduction zones. Earth and Planetary Science Letters, 445, 146-159.

Piccoli, F., Brovarone, A.V., and Ague, J.J. (2018) Field and petrological study of metasomatism and high-pressure carbonation from lawsonite eclogite-facies terrains, Alpine Corsica. Lithos, 304, 16-37.

Plank, T., and Langmuir, C.H. (1998) The chemical composition of subducting sediment and its consequences for the crust and mantle. Chemical Geology, 145(3), 325-394

Poli, S. (2015) Carbon mobilized at shallow depths in subduction zones by carbonatitic liquids. Nature Geoscience, $8(8), 633$

Power, I.M., Harrison, A.L., and Dipple, G.M. (2016) Accelerating mineral carbonation using carbonic anhydrase. Environmental Science and Technology, $50(5), 2610-2618$.

Rahman, S., Aller, R.C., and Cochran, J.K. (2017) The missing silica sink: Revisiting the marine sedimentary Si cycle using cosmogenic ${ }^{32} \mathrm{Si}$. Global Biogeochemical Cycles, 31(10), 1559-1578

Raymo, M.E., and Ruddiman, W.F. (1992) Tectonic forcing of late Cenozoic climate. Nature, 359,117

Ronov, A.B., Yaroshevskii, A.A., and Migdisov, A.A. (1990) Chemical Structure of the Earth's Crust and Geochemical Balance of Major Elements. Nauka, Moscow.

Royer, D.L., Berner, R.A., Montañez, I.P., Tabor, N.J., and Beerling, D.J. (2004) $\mathrm{CO}_{2}$ as a primary driver of phanerozoic climate. GSA Today, 14(3), 4-10.

Rumble, D., Ferry, J.M., Hoering, T.C., and Boucot, A.J. (1982) Fluid flow during metamorphism at the Beaver Brook fossil locality, New Hampshire. American Journal of Science, 282(6), 886-919.

Sagan, C. (1962) Structure of the lower atmosphere of Venus. Icarus, 1(1-6), 151-169.

Sagan, C., and Mullen, G. (1972) Earth and Mars: Evolution of atmospheres and surface temperatures. Science, 177, 52-56.

Sakai, H., Gamo, T., Kim, E.S., Tsutsumi, M., Tanaka, T., Ishibashi, J., and Oomori, T. (1990) Venting of carbon dioxide-rich fluid and hydrate formation in midOkinawa trough backarc basin. Science, 248, 1093-1096.

Sano, Y., and Williams, S.N. (1996) Fluxes of mantle and subducted carbon along convergent plate boundaries. Geophysical Research Letters, 23(20), $2749-2752$.

Scambelluri, M., Bebout, G.E., Belmonte, D., Gilio, M., Campomenosi, N., Collins, N., and Crispini, L. (2016) Carbonation of subduction-zone serpentinite (highpressure ophicarbonate; Ligurian Western Alps) and implications for the deep carbon cycling. Earth and Planetary Science Letters, 441, 155-166.

Sieber, M.J., Hermann, J., and Yaxley, G.M. (2018) An experimental investigation of C-O-H fluid-driven carbonation of serpentinites under forearc conditions. Earth and Planetary Science Letters, 496, 178-188.

Siever, R. (1968) Sedimentological consequences of a steady-state ocean-atmosphere. Sedimentology, 11(1-2), 5-29. 
Sillén, L.G. (1961) The physical chemistry of sea water. Oceanography, 67, $549-581$.

Skelton, A. (2011). Flux rates for water and carbon during greenschist facies metamorphism. Geology, 39(1), 43-46.

Sleep, N.H., and Zahnle, K. (2001) Carbon dioxide cycling and implications for climate on ancient Earth. Journal of Geophysical Research: Planets, 106(E1), 1373-1399.

Solomon, E.A., Spivack, A.J., Kastner, M., Torres, M.E., and Robertson, G. (2014) Gas hydrate distribution and carbon sequestration through coupled microbial methanogenesis and silicate weathering in the Krishna-Godavari basin, offshore India. Marine and Petroleum Geology, 58, 233-253.

Staudigel, H., Hart, S.R., Schmincke, H.U., and Smith, B.M. (1989) Cretaceous ocean crust at DSDP Sites 417 and 418: Carbon uptake from weathering versus loss by magmatic outgassing. Geochimica et Cosmochimica Acta, 53(11), 3091-3094.

Stewart, E.M., and Ague, J J (2018) Infiltration-driven metamorphism, New England, USA: Regional $\mathrm{CO}_{2}$ fluxes and implications for Devonian climate and extinctions. Earth and Planetary Science Letters, 489, 123-134.

Sverjensky, D.A., Stagno, V., and Huang, F. (2014) Important role for organic carbon in subduction-zone fluids in the deep carbon cycle. Nature Geoscience, 7(12), 909.

Tao, R., Zhang, L., Li, S., Zhu, J., and Ke, S. (2018) Significant contrast in the $\mathrm{Mg}-\mathrm{C}-\mathrm{O}$ isotopes of carbonate between carbonated eclogite and marble from the SW Tianshan UHP subduction zone: Evidence for two sources of recycled carbon. Chemical Geology, 483, 65-77.

Tian, M., and Ague, J.J. (2014) The impact of porosity waves on crustal reaction progress and $\mathrm{CO}_{2}$ mass transfer. Earth and Planetary Science Letters, 390, $80-92$.

Tracy, R.J., Rye, D.M., Hewitt, D.A., and Schiffries, C.M. (1983) Petrologic and stable-isotopic studies of fluid-rock interactions, south-central Connecticut: I.
The role of infiltration in producing reaction assemblages in impure marbles. American Journal of Science, 283, 589-616.

Urey, H.C. (1952) The Planets: Their Origin and Development. Yale University Press.

Varekamp, J.C., Kreulen, R., Poorter, R.P.E., and Van Bergen, M.J. (1992) Carbon sources in arc volcanism, with implications for the carbon cycle. Terra Nova, 4(3), 363-373.

Walker, J.C., Hays, P.B., and Kasting, J.F. (1981) A negative feedback mechanism for the long-term stabilization of Earth's surface temperature. Journal of Geophysical Research: Oceans, 86(C10), 9776-9782.

Wallmann, K., Aloisi, G., Haeckel, M., Tishchenko, P., Pavlova, G., Greinert, J., and Eisenhauer, A. (2008) Silicate weathering in anoxic marine sediments. Geochimica et Cosmochimica Acta, 72(12), 2895-2918.

White, A.F., and Blum, A.E. (1995) Effects of climate on chemical weathering in watersheds. Geochimica et Cosmochimica Acta, 59(9), 1729-1747.

Wilde, S.A., Valley, J.W., Peck, W.H., and Graham, C.M. (2001) Evidence from detrital zircons for the existence of continental crust and oceans on the Earth 4.4 Gyears ago. Nature, 409, 175 .

Wilson, S.A., Dipple, G.M., Power, I.M., Thom, J.M., Anderson, R.G., Raudsepp, M., and Southam, G. (2009) Carbon dioxide fixation within mine wastes of ultramafic-hosted ore deposits: Examples from the Clinton Creek and Cassiar chrysotile deposits, Canada. Economic Geology, 104(1), 95-112.

Winnick, M.J., and Maher, K. (2018) Relationships between $\mathrm{CO}_{2}$, thermodynamic limits on silicate weathering, and the strength of the silicate weathering feedback. Earth and Planetary Science Letters, 485, 111-120.

MANUSCRIPT RECEIVED NOVEMBER 7, 2018

MANUSCRIPT ACCEPTED JUNE 17, 2019

MANUSCRIPT HANDLED BY SIMON REDFERN 